\title{
Pengaruh inflasi, nilai tukar rupiah per dollar Amerika, harga minyak mentah dunia dan indeks harga saham gabungan terhadap harga emas di Indonesia
}

\author{
Fadhel Kesarditama*, Haryadi, Yohanes Vyn Amzar \\ Prodi Ekonomi Pembangunan Fak. Ekonomi dan Bisnis Universitas Jambi \\ *E-mail korespondensi: fadhelk1@gmail.com
}

\begin{abstract}
This study aims to analyze the trend of macroeconomic variables and gold prices in Indonesia and to determine the effect of macroeconomic variables on gold prices in Indonesia. This study uses a quantitative approach. The data used is secondary data from January 2014-December 2019. The analytical tools and techniques used are trend analysis with a linear trend approach and multiple linear regression models using the Ordinary Least Square method. The five research variables that were processed showed that there were differences in the direction of the data trend. Where the variables of Gold Price, Exchange Rate, and Composite Stock Price Index show a positive trend, while the variables of Inflation and World Crude Oil Prices show a negative trend. Furthermore, the variables of Exchange Rate, world Crude Oil Price, and Composite Stock Price Index show a positive and significant influence on the Gold Price in Indonesia. While the inflation variable shows a negative and significant effect on the Gold Price in Indonesia.
\end{abstract}

Keywords: Inflation, foreign exchange,crude oil prices, idx composite and gold prices

\begin{abstract}
Abstrak
Penelitian ini bertujuan untuk menganganalisis trend variabel makroekonomi dan harga emas di Indonesia serta untuk mengetahui pengaruh variabel makroekonomi terhadap harga emas di Indonesia. Penelitian ini menggunakan pendekatan kuantitatif. Data yang digunakan berupa data sekunder dari Januari2014-Desember2019. Alat analisis dan teknik yang digunakan adalah analisis trend dengan pendekatan trend linear serta model regresi linear berganda dengan metode Ordinary Least Square. Kelima variabel penelitian yang diolah memperlihatkan ada perbedaan arah trend data. Dimana Variabel Harga Emas, Nilai Tukar, dan Indeks Harga Saham Gabungan menunjukan trend yang positif sedangkan variabel Inflasi dan Harga Minyak Mentah Dunia menunjukan trend yang negatif. Selanjutnya variabel Nilai Tukar, Harga Minyak Mentah dunia dan Indeks Harga Saham Gabungan menunjukan pengaruh yang positif dan signifikan terhadap Harga Emas di Indonesia. Sedangkan variabel inflasi menunjukan pengaruh yang negatif dan signifikan terhadap Harga Emas di Indonesia.
\end{abstract}

Kata kunci: Inflasi, nilai tukar, harga minyak mentah dunia, ihsg, emas

\section{PENDAHULUAN}

Kondisi harga emas dunia dalam beberapa tahun terakhir mengalami fluktuasi yang cukup signifikan dari puncak kejayaan di tahun 2012 pada kisaran 1.800 US\$/Toz dan terus merosot pada periode-periode berikutnya. Menurut Laporan Tahunan PT 
ANTAM Tbk (2018) menunjukan bahwa pada tahun 2014 harga emas dunia berada pada posisi $1.277,32$ US $\$ /$ Toz selanjutnya pada tahun 2015 posisi harga emas dunia berada pada angka 1.215,69 US\$/Toz.

Berikutnya pada tahun 2016 banyak peristiwa penting yang memberikan dampak kepada harga emas global. Pada tahun ini harga emas dunia berada pada posisi 1.265,66 US\$/Toz yang menunjukan kenaikan dari tahun sebelumnya. Kenaikan harga emas ini salah satunya diakibatkan oleh keluarnya Inggris dari keanggotaan Uni Eropa, yang dikenal dengan istilah Brexit. Dampak brexit ini bisa menjalar kepada perekonomian dunia, harga minyak mentah dunia serta nilai tukar poundsterlingpun merosot yang membuat perusahaan global mulai mempertimbangkan untuk anjak kaki dari Inggris yang tentu saja mempengaruhi iklim investasi.

Disamping itu terpilihnya Donald Trump sebagai Presiden Amerika Serikat juga mengakibatkan ketidakpastian dalam perekonomian. Pasalnya, banyak kebijakan ekonomi pada masa kampanye Donald Trump yang dianggap terlalu kontroversial yang dapat mempengaruhi iklim perekonomian global. Beberapa kebijakan tersebut adalah pemangkasan pajak, belanja pemerintah, hingga deregulasi aturan. Namun salah satu kebijakan Trump yang dianggap riskan adalah proteksionisme perdagangan sehingga para investor mulai memburu emas untuk melindungi nilai kekayaan mereka atas ketidakpastian risiko investasi yang mereka alami.

Ketidakpastian yang dialami para investor juga terjadi di tahun 2017, dimana kekhawatiran akan munculnya perang Korea Utara dan Amerika Serikat yang mendorong kenaikan harga emas dunia. Pada tahun 2017 harga emas tercatat mengalami kenaikan dari tahun sebelumnya menjadi 1.293 US\$/Toz. Berlanjut ke tahun 2018 tercatat harga emas naik ke angka 1.309,30 US\$/Toz hal ini terjadi karena adanya perang dagang yang terjadi antara Amerika Serikat dengan Republik Rakyat Tiongkok.

Gejolak geopolitik dan ekonomi tersebut sangat berdampak kepada iklim perekonomian nasional. Kondisi-kondisi diatas dapat membuat perekonomian nasional bergejolak, yang paling peka terhadap fenomena tersebut adalah inflasi dan nilai tukar. Inflasi dapat melambung tinggi dan nilai tukar dapat terdepresiasi terhadap mata uang negara lain. Dalam hal tersebut para investor akan terus mengalami peningkatan risiko dalam berinvestasi dan para investor juga akan mencari cara untuk melindungi aset mereka.

Menurut penelitian sebelumnya yang dilakukan di berbagainegara jika tingkat inflasi tinggi, nilai tukar yang terapresiasi harga minyak dunia tinggi dan kelesuan pada indeks saham maka investor akan berbondong bondong membeli emas. Seperti yang dijelaskan oleh Tyson (2011) bahwa emas merupakan salah satu investasi yang terpercaya yang dapat memberi keuntungan secara finansial yang baik untuk investor. Selain itu emas juga memiliki resiko lebih kecil dibandingkan investasi saham ataupun investasi pada instrumen lainya.Karena emas dianggap lebih tahan terhadap gejolak perekonomian tersebut dibandingkan investasi lain. Berdasarkan latar belakang tersebut, penelitian ini bertujuan untuk: (1) menganalisis bagaimana trend inflasi, nilai tukar, Harga MinyakMentah Dunia, IHSG dan harga emas di Indonesia (2) menganalisis bagaimana pengaruh inflasi, nilai tukar, Harga Minyak Mentah Dunia dan IHSG terhadap harga emas di Indonesia.

\section{METODE}

Jenis data pada penelitian ini adalah data sekunder deret waktu yang berbentuk bulanan dari Januari 2014 - Desember 2018. Sumber data yang dikumpulkan dalam penelitian ini diperoleh dari data publikasi yang diterbitkan pada situs web 
instansidanlembaga yang terpercaya, yaitu : (1) PT. Logam Mulia (Persero), Tbk (2) Bank Indonesia (3) New York Mercantile Exchange, Inc (4) Bursa Efek Indonesia. Alat analisis yang digunakan yakni analisis trend dan regresi linear berganda. Model analisis trend metode Least Square sebagai berikut :

$$
\boldsymbol{Y}=\boldsymbol{a}+\boldsymbol{b} \boldsymbol{X}
$$

Model regresi berganda untuk menganalisis faktor-faktor yang mempengaruhi hargaemasadalah sebagai berikut:

$$
\text { Gold }_{t}=\beta_{0}+\beta_{1} \text { inf }_{t}+\beta_{2} \text { uurs }_{t}+\beta_{3} C O_{t}+\beta_{4} I H S G_{t}+e_{t}
$$

Keterangan:

Gold $_{t}=$ Harga emas

Kurs $_{t}=$ Nilai tukar rupiah terhadap USD gabungan

$\operatorname{Inf}_{t}=$ Inflasi

$\mathrm{CO}_{t} \quad$ = Harga minyak mentah dunia

$I H S G_{t}=$ Indeks harga saham

$e_{t} \quad=$ error $/$ residual penganggu

\section{HASIL DAN PEMBAHASAN}

Untuk menganalisis bagaimana trend variabel makroekonomi dan harga emas di Indonesia digunakanlah persamaan trend metode Least Square $\mathrm{Y}=\mathrm{a}+\mathrm{bX}$ dengan menggunakan software Microsoft Excel 2007 yang telah di lengkapi dengan Add-in Data Analysis untuk mengetahui nilai a dan nilai b sehingga persamaan tersebut bisa digunakan untuk meramalkan kondisi di masa yang akan datang.

\section{Tren harga emas}

Harga emas di Indonesia tentu saja mengikuti bagaimana harga emas dunia. Harga emas dunia dipengaruhi oleh faktor ekonomi seperti jumlah penawaran, permintaan, dan produksi emas, namun selain faktor tersebut faktor isu politik juga dapat menyebabkan kenaikan harga emas dunia. Isu politik seperti resesi global, perselisihan antar negara dapat menjadi penyebab pergerakan harga emas dunia.

Dari perhitungan yang dilakukan menggunakan software Microsoft Excel 2007 diperoleh nilai $b$ dan a sebagai berikut:

Tabel 1. Hasil output coefficient analisis tren harga emas

\begin{tabular}{lc}
\hline Intercept & 525474,6 \\
$X$ Variable & 2147,53213 \\
\hline
\end{tabular}

Sumber: Data diolah, 2019

Dari Tabel 1 didapatkan nilai b (X Variable) adalah 2147,53212 dan nilai a (intercept) adalah 525474,6. Dengan demikian didapatkan persamaan Tren Harga Emas sebagai berikut.

$$
\square_{1}=\mathbf{5 2 5 4 7 4 , 6}+\mathbf{2 1 4 7 , 5 3 2 1 2}
$$

Dari persamaan tersebut diperoleh tren positif pada harga emas yakni kecendrungan nilai ramalan harga emas (Y) naik seiring dengan meningkatnya waktu. Berikut ini adalah grafik inflasi periode Januari 2014-Desember 2018. 
Berdasarkan Gambar 1. tersebut, harga emas di Indonesia selalu mengalami kenaikan dan penurunan. Namun secara keseluruhan yakni dari Januari 2014 - Desember 2018

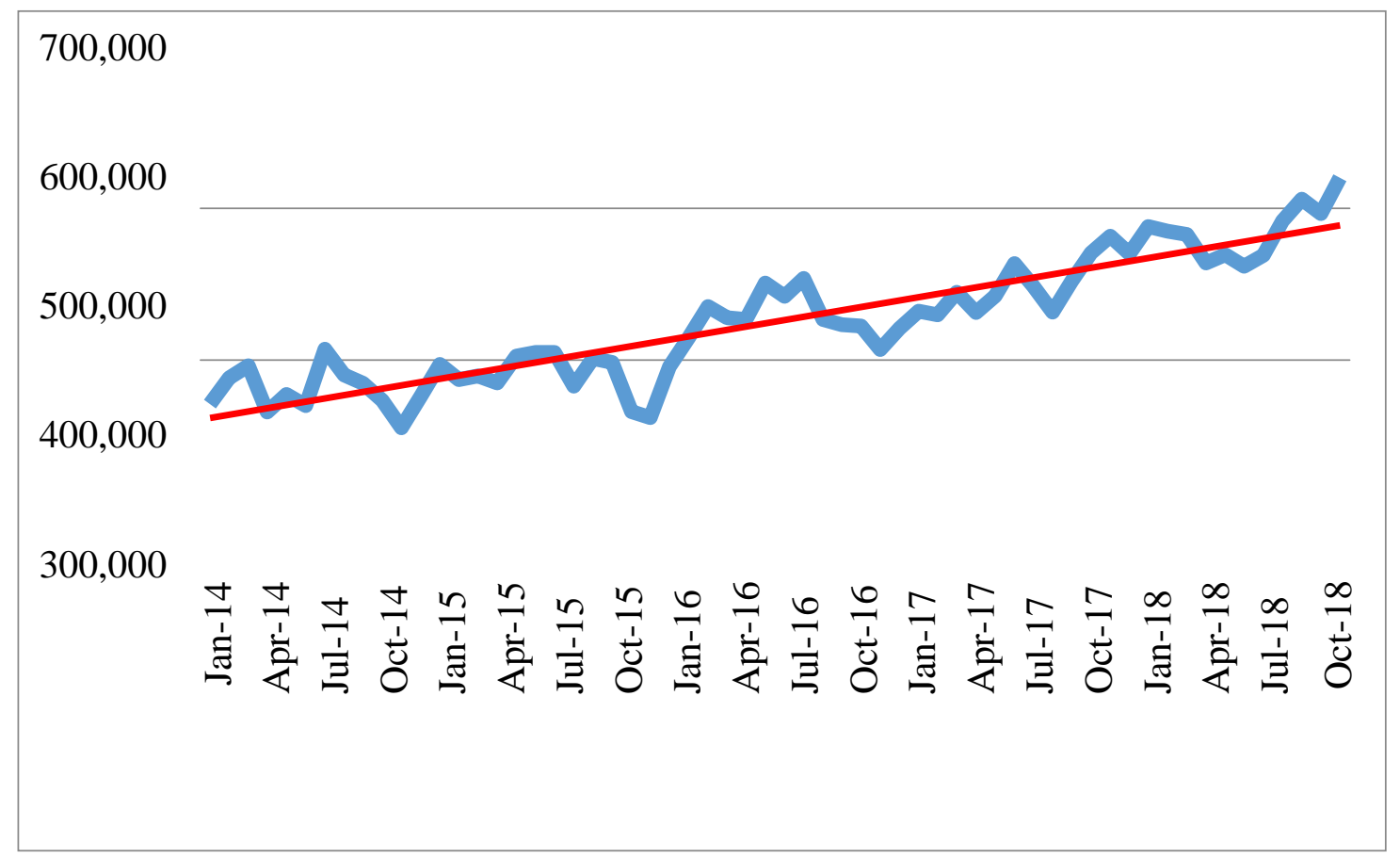

membentuk tren yang naik seperti yang terlihat pada Gambar 1.Pada Januari 2014 harga berada pada harga Rp471.292/gram dan terus mengalami kenaikan dan penurunan.

Sumber: Data diolah, 2019

Gambar 1. Tren harga emas Januari 2014 - Desember 2018

\section{Tren tingkat inflasi di Indonesia}

Indonesia mengalami kenaikan serta penurunan angka inflasi setiap tahunnya. Angka inflasi sejak 2014 - 2018 yang terbesar berada padatahun 2014 sebesar 8,36\%, sedangkan angka inflasi terendah berhasil dicapai pada 2016 dengan inflasi sebesar 3,02\%. Dari perhitungan yang dilakukan menggunakan software Microsoft Excel 2007 diperoleh nilai $b$ dan a sebagai berikut.

Tabel 2. Hasil output coefficient analisis tren inflasi

\begin{tabular}{lc}
\hline Variabel & Coefficients \\
\hline Intercept & 0,04667 \\
X Variable & $-0,00076$ \\
\hline
\end{tabular}

Sumber: Data diolah, 2019

Dari Tabel 2 didapatkan nilai b (X Variable) adalah -0,00076 dan nilai a (intercept) adalah 0,04667. Dengan demikian didapatkan persamaan Tren Inflasi sebagai berikut.

$$
\square_{2}=\mathbf{0 , 0 4 6 6 7}-\mathbf{0 , 0 0 0 7 6}
$$

Dari persamaan tersebut diperoleh tren negatif pada inflasi yakni kecendrungan nilai ramalan tingkat inflasi (Y) turun seiring dengan meningkatnya waktu. Berikut ini adalah grafik tingkat inflasi periode Januari 2014-Desember 2018. 
Berdasarkan Gambar 2. terlihat bahwa tingkat inflasi di Indonesia mengalami fluktuasi namun cenderung membentuk trend yang menurun. Hal ini dapat dilihat bahwa pada awal tahun 2014 inflasi berada pada angka 8,22\% namun terus mengalami penurunan meskipun pada pertengahan tahun 2014 sempat mengalami kenaikan tipis tetapi pada bulan selajutnya angka inflasi meluncur tajam higga ke anngka 3,99\%. Angka inflasi kembali naik di akhir tahun 2014 dan kembali berfluktuasi dari tahun 2015 dan cenderung mengalami penurunan hingga akhir 2018.

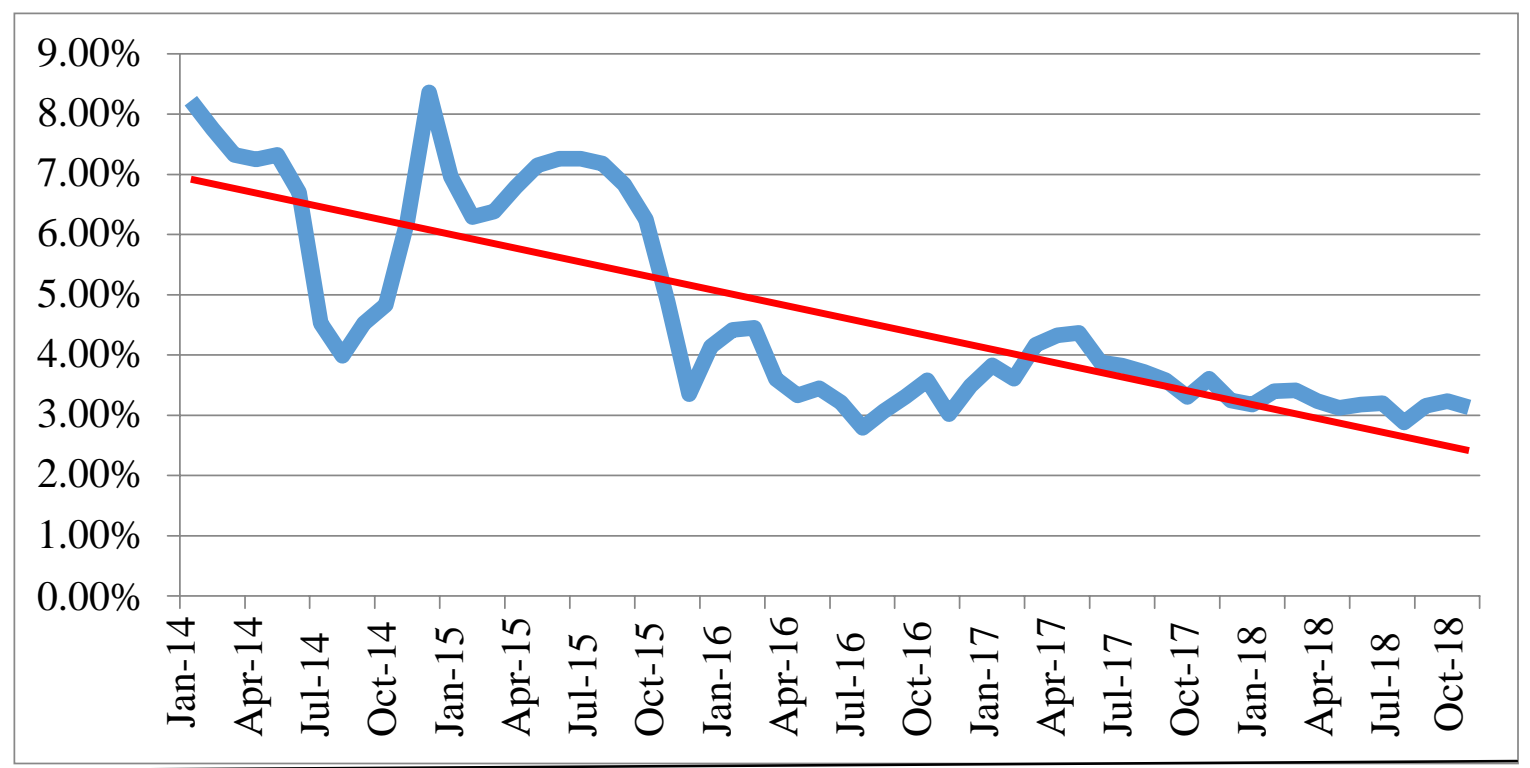

Sumber: Data diolah, 2019

Gambar 2. Tren inflasi Januari 2014 - Desember 2018

\section{Tren nilai tukar}

Ketergantungan terhadap bahan baku impor dalam jumlah yang besar menjadi salah satu penyebab melemahnya nilai rupiah terhadap dollar AS. Tingginya impor tersebut memicu neraca perdagangan yang defisit. Sehingga secara perlahan nilai dollar terus meningkat terhadap rupiah. Faktor dari luar seperti berkembangnya isu rencana The Fed meningkatkan suku bunga acuan juga berpengaruh terhadap nilai rupiah. Dari perhitungan yang dilakukan menggunakan software Microsoft Excel 2007 diperoleh nilai $b$ dan a sebagai berikut.

Tabel 3. Hasil output coefficient analisis trend nilai tukar

\begin{tabular}{lc}
\hline Variabel & Coefficients \\
\hline Intercept & 13251,7 \\
X Variable & 41,78894 \\
\hline
\end{tabular}

Sumber: Data diolah, 2019

Dari tabel diatas didapatkan nilai b (X Variable) adalah 41,78894 dan nilai a (intercept) adalah 13251,7. Dengan demikian didapatkan persamaan Tren Nilai Tukar sebagai berikut.

$$
\square_{3}=\mathbf{1 3 2 5 1 , 7}+\mathbf{4 1 , 7 8 8 9 4}
$$

Dari persamaan tersebut diperoleh tren positif pada nilai tukar yakni kecendrungan 
nilai ramalan Nilai Tukar (Y) naik seiring dengan meningkatnya waktu. Berikut adalah grafik Nilai Tukar periode Januari 2014-Desember 2018.

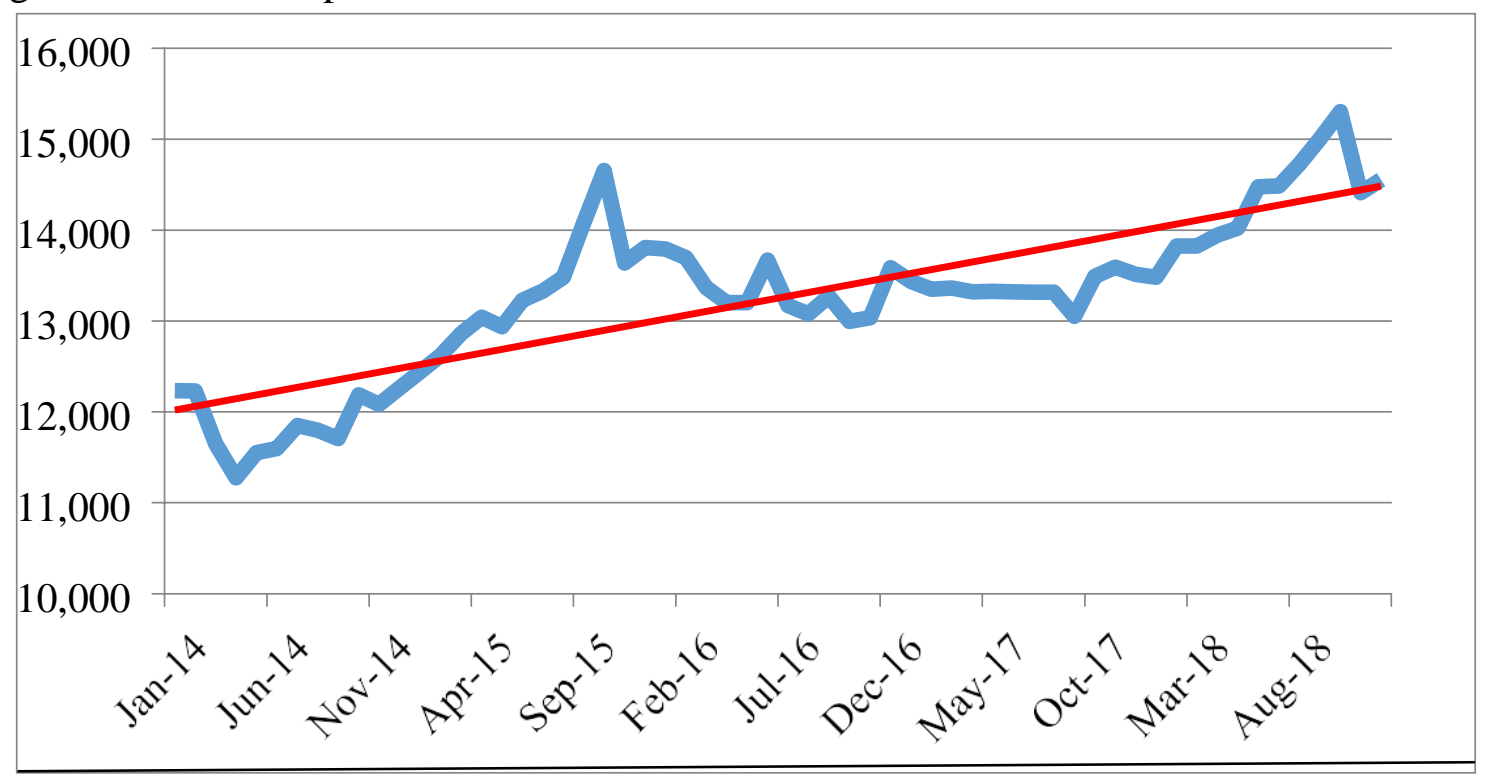

Sumber: Data diolah, 2019

Gambar 3. Tren nilai tukar Januari 2014 - Desember 2018

Dari Gambar 3 tersebut terlihat bahwa nilai tukar rupiah per dollar Amerika pada awal tahun 2014 cenderung bergerak konstan dan mengalami penguatan atau terapresiasi terhadap dollar Amerika. Selanjutnya nilai tukar rupiah per dollar Amerika terus mengalami penguatan dan pelemahan namun cenderung membentuk tren pelemahan. Terlihat dimana pada Oktober 2015 rupiah sempat berada pada angka Rp. 14.654/US\$ dan pada bulan berikutnya terus mengalami fluktuasi dan cenderung di kisaran angka Rp.13.000/US\$. Pada pertengahan hingga akhir 2018 nilai tukar rupiah per dollar Amerika mulai memperlihatkan suatu pelemahan hingga menembus Rp.15.303/US\$.

\section{Tren harga minyak mentah dunia}

Harga minyak mentah dunia sangat berfluktuasi dalam periode 2014-2018. Pada awal tahun 2014 harga minyak mentah dunia berada pada angka 100US\$/barel dan terus mengalami penurunan hingga Desember 2014 harga minyak mentah dunia hanya mampu mencapai harga 48.24US\$/barel. Selanjutnya harga minyak mentah dunia terus mengalami penurunan hingga puncaknya pada bulan Desember 2015. Namun pada periode selanjutnya harga minyak mentah dunia kembali menunjukan kenaikan yangdisebabkan tingginya permintaan serta meningkatnya faktor geopolitik khususnya antara Amerika Serikat dengan Tiongkok. Dari perhitungan yang dilakukan menggunakan software Microsoft Excel 2007 diperoleh nilai b dan a sebagai berikut.

Tabel 4. Hasil output coefficient analisis tren harga minyak mentah dunia

\begin{tabular}{lc}
\hline Variabel & Coefficients \\
\hline Intercept & 59,7385 \\
$X$ Variable & $-0,36614$ \\
\hline
\end{tabular}

Sumber: Data diolah, 2019

Dari tabel diatas didapatkan nilai b (X Variable) adalah 59,7385 dan nilai a 
(intercept) adalah -0,36614. Dengan demikian didapatkan persamaan Tren Harga Minyak Mentah Duniaadalah sebagai berikut.

$$
\square_{5}=\mathbf{5 9 , 7 3 8 5}-\mathbf{0 , 3 6 6 1 4}
$$

Dari persamaan tersebut diperoleh tren negatif pada Harga Minyak Mentah Dunia yakni kecendrungan nilai ramalan Y turun seiring dengan meningkatnya waktu. Berikut adalah grafik harga minyak mentah dunia periode Januari 2014-Desember 2018.

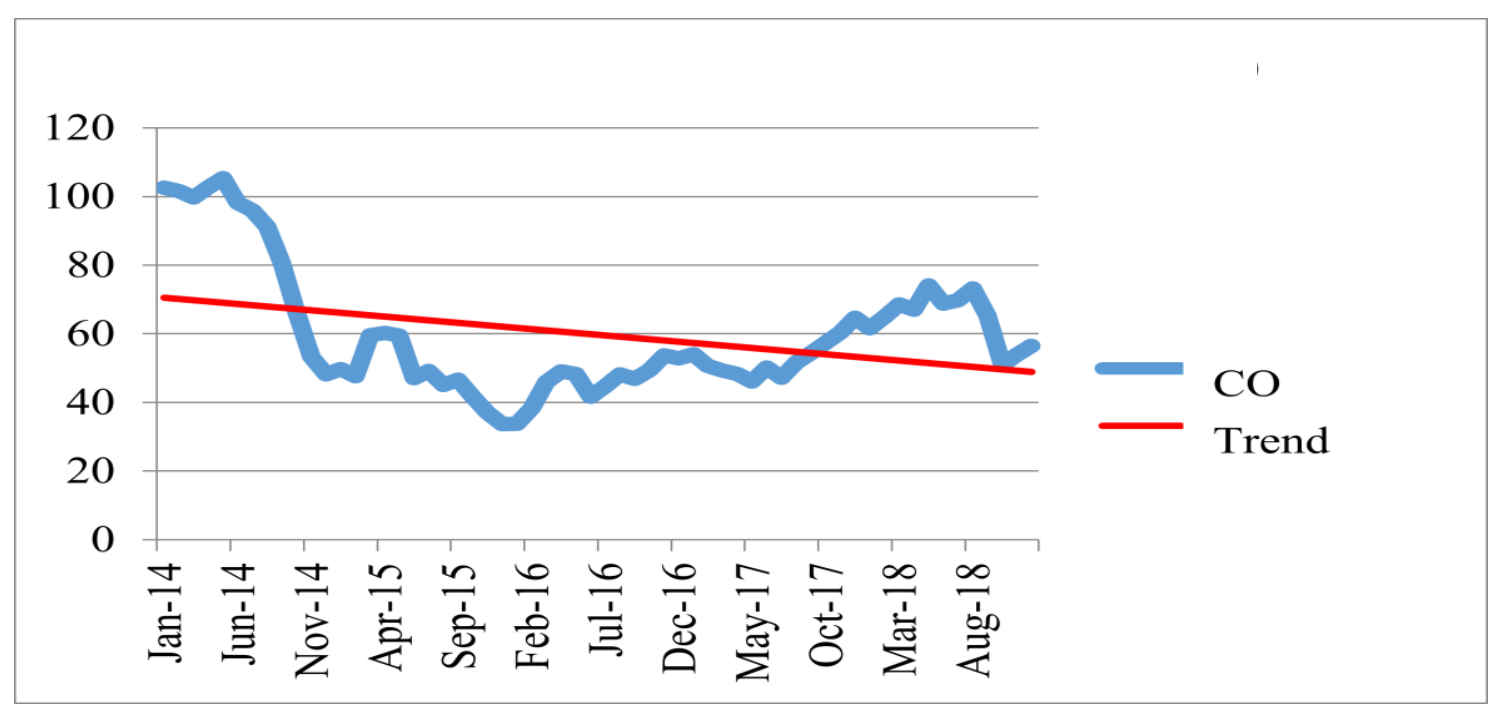

Sumber: Data diolah, 2019

Gambar 4. Tren harga minyak mentah dunia Januari 2014 - Desember 2018

Minyak mentah dunia menunjukan suatu fluktusi harga, hal ini terlihat pada Gambar 4 yang menunjukan pada awal 2014 harga minyak mentah dunia cenderung menurun tipis dan mengalami lonjakan pada pertengahan tahun 2014. Selanjutnya penurunan harga terjadi cukup tajam pada pertengahan hingga penutupan tahun 2014 . Pada tahun-tahun berikutnya harga minyak mentah dunia terus berfluktuasi yang terlihat pada Gambar 4. dan membentuk trend yang cenderung menurun.

\section{Tren indeks harga saham gabungan}

Pada tahun 2014 IHSG di buka dengan nilai 4256,44 poin dimana terus mengalami naik dan turun sampai dengan bulan September yang mengalami penguatan sampai dengan Desember yang ditutup menguat 5149,89 poin. Selanjutnya pada tahun 2015 IHSG mengalami kelesuan sehingga berakhir pada angka 4446,46 poin pada penutupan tahun tersebut. Hal ini dampak dari pengetatan kebijakan moneter Amerika Serikat dan Perlambatan ekonomi Tiongkok. Dari perhitungan yang dilakukan menggunakan software Microsoft Excel 2007

diperoleh nilai $b$ dan a sebagai berikut.

Tabel 5. Hasil output coefficient analisis tren indeks harga saham gabungan

\begin{tabular}{lc}
\hline Variabel & Coefficients \\
\hline Intercept & 5325,1911 \\
X Variable & 29,420971
\end{tabular}

Sumber: Data diolah, 2019 
Dari tabel diatas didapatkan nilai b (X Variable) adalah 29,420971 dan nilai a (intercept) adalah 5325,1911. Dengan demikian didapatkan persamaan Tren Indeks Harga Saham Gabungan sebagai berikut.

\section{$\square_{6}=\mathbf{5 3 2 5 , 1 9 1 1}+\mathbf{2 9 , 4 2 0 9 7 1}$}

Dari persamaan tersebut diperoleh tren positif pada indeks harga saham gabungan yakni kecendrungan nilai ramalan harga emas (Y) naik seiring dengan meningkatnya waktu. Berikut ini adalah grafik Indeks Harga Saham Gabungan periode Januari 2014Desember 2018.

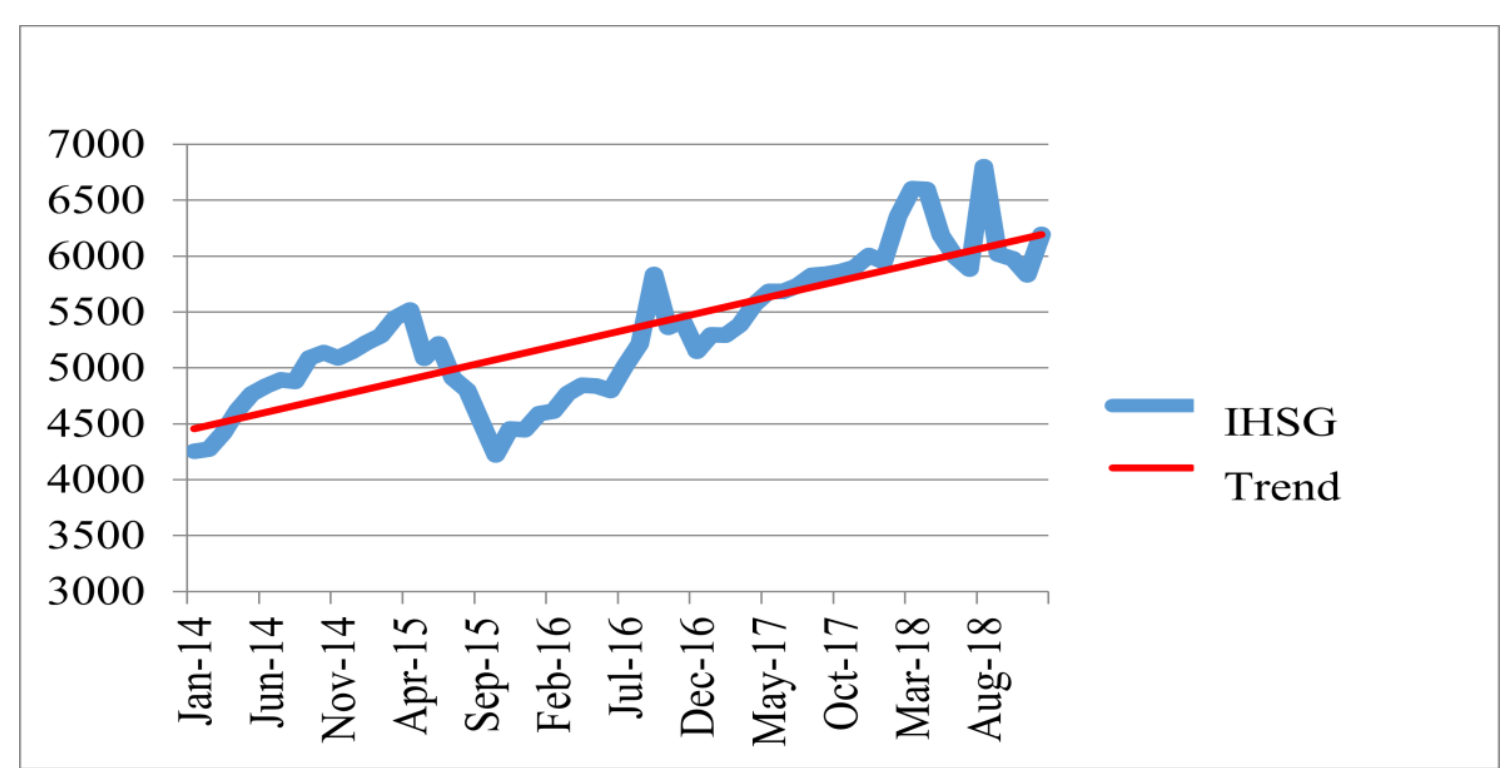

Sumber: Data diolah, 2019

Gambar 5. Tren indeks harga saham gabungan Januari 2014 - Desember 2018

Awal tahun 2014 IHSG mengalami penguatan hingga pertengahan tahun 2015 IHSG menunujkan suatu pelemahan. Pada tahun 2016 - 2018 terlihat kembali terjadi kegairahan pada Terlihat pada akhir 2017 IHSG sudah menyentuh angka 6000 poin dan terus berlanjut sampai ke tahun 2018 yang mana titik tertinggi terjadi pada bulan Maret 2018. Meskipun berfluktuasi IHSG membentuk trend yang positif atau naik.

\section{Pengaruh variabel makroekonomi terhadap harga emas di Indonesia}

Untuk mengetahui pengaruh variabel makroekonomi terhadap harga emas di Indonesia, digunakan analisis Regresi Linear Berganda dengan metode Ordinary Least Square (OLS), serta dibantu dengan Software Eviews 8.

Uji simultan (uji F) dilakukan untuk melihat pengaruh seluruh variabel independen secara bersama-sama mempengaruhi variabel dependen. Berdasarkan hasil estimasi didapatkan nilai F-hitung sebesar 56.70851 dengan probabilita 0,00000 (< $\alpha=0,0005$ ). Artinya secara bersama-sama seluruh variabel makroekonomi berpengaruh signifikan terhadap harga emas di Indonesia

Berdasarkan hasil perhitungan koefisien determinasi atau goodness of fit diperoleh angka sebesar 0,804850. Nilai koefisien determinasi $\left(\mathrm{R}^{2}\right)$ sebesar 80,4\%, hal ini menunjukkan variabel independen mampu menjelaskan variabel dependen sebesar80,4\%, sedangkan sisanyas ebesar $19,6 \%$ dijelaskan oleh variabel lain yang tidak masuk dalam model. 
Tabel 6. Hasil estimasi

\begin{tabular}{clcrr}
\hline Variabel & Coefficient & Std. Error & t-Statistic & \multicolumn{1}{c}{ Prob. } \\
\hline C & 123809,3 & 59342,52 & 2.086350 & 0.0416 \\
Inflasi & $-7181,238$ & 1963.260 & $-3,657812$ & 0.0006 \\
Kurs & 20,06989 & 4,019414 & 4,993238 & 0.0000 \\
CO & 432,1979 & 165,3546 & 2,613763 & 0.0115 \\
IHSG & 26,91172 & 5,185499 & 5,189803 & 0,0000 \\
\hline R-squared & 0.804850 & Mean dependent var & 525376.7 \\
Adjusted R-squared & 0.790657 & S.D. dependent var & 41352.41 \\
S.E. of regression & 18920.39 & Akaike info criterion & 22.61352 \\
Sum squared resid & $1.97 \mathrm{E}+10$ & Schwarz criterion & 22.78805 \\
Log likelihood & -673.4057 & Hannan-Quinn criter. & 22.68179 \\
F-statistic & 56.70851 & Durbin-Watson stat & 0.890934 \\
Prob(F-statistic) & 0.000000 & & \\
\hline
\end{tabular}

Sumber: Data diolah, 2019

Selanjutnya uji parsial (uji t) dilakukan untuk mengetahui pengaruh tiap-tiap variabel bebas (inflasi, nilai tukar rupiah terhadap dollar Amerika, harga minyak mentah dunia dan indeks harga saham gabungan) terhadap variabel terikat (harga emas)

\section{Pengaruh inflasi terhadap harga emas}

Hasil analisis menunjukkan bahwa variabel inflasi memiliki t-statistic sebesar 3,6567812 dan probabilitas sebesar 0,0005. Dalam taraf signifikansi 5\% maka variabel inflasi secara individu signifikan dalam mempengaruhi harga emas di Indonesia.

\section{Pengaruh kurs terhadap harga emas}

Hasil analisis menunjukkan bahwa variabel kurs memiliki t-statistic sebesar 4,993238 dan probabilitas sebesar 0,0000. Dalam taraf signifikansi 5\% maka variabel kurs secara individu signifikan dalam mempengaruhi harga emas di Indonesia.

\section{Pengaruh harga minyak mentah dunia terhadap harga emas}

Hasil analisis menunjukkan bahwa variabel harga minyak mentah dunia memiliki t-statistic sebesar 2,613763 dan probabilitas sebesar 0,0115. Dalam taraf signifikansi $5 \%$ maka variabel harga minyak mentah dunia secara individu signifikan dalam mempengaruhi harga emas di Indonesia.

\section{Pengaruh indeks harga saham gabungan terhadap harga emas}

Hasil analisis menunjukkan bahwa variabel indeks harga saham gabungan memiliki t-statistic sebesar 5,189803 dan probabilitas sebesar 0,0000. Dalam taraf signifikansi $5 \%$ maka variabel indeks harga saham gabungan secara individu signifikan dalam mempengaruhi harga emas di Indonesia.

\section{KESIMPULAN DAN SARAN}

\section{Kesimpulan}

Hasil analisis trend menunjukan bahwa ada perbedaan arah trend pada variabel penelitian. Variabel Harga Emas, Nilai Tukar, dan Indeks Harga Saham Gabungan menunjukan trend yang positif sedangkan variabel Inflasi dan Harga Minyak Mentah Dunia menunjukan trend yang negatif. 
Dari hasil regresi linear berganda ditemukan bahwa variabel Nilai Tukar, Harga Minyak Mentah dunia dan Indeks Harga Saham Gabungan menunjukan pengaruh yang positif dan signifikan terhadap Harga Emas di Indonesia. Sedangkan variabel inflasi menunjukan pengaruh yang negatif dan signifikan terhadap Harga Emas di Indonesia Secara bersama-sama inflasi, nilai tukar (kurs) Rupiah terhadap USD, Harga Minyak Mentah Dunia dan Indeks Harga Saham Gabungan memiliki pengaruh yang signifikan terhadap harga emas. Besarnya pengaruh yang disebabkan oleh keempat variabel independen tersebut adalah sebesar 80,4\%, sedangkan sisanya sebesar 19,6\% dijelaskan oleh variabel lain diluar model penelitian.

\section{Saran}

Sebaiknya investor juga menggunakan informasi-informasi lainnya yang dapat digunakan untuk referensi dalam pengambilan keputusan berinvestasi karena tentu banyak factor lain yang mempengaruhi pergerakan harga emas selain faktor-faktor yang digunakan dalam penelitian ini.

Penelitian ini hanya menggunakan empat variabel bebas sementara faktor-faktor yang mempengaruhi harga emas tentunya lebih banyak selain yang digunakan dalam penelitian ini. Oleh karena itu untuk penelitian selanjutnya diharapkan agar menggunakan kombinasi dengan variabel-variabel independen lainnya. Selain itu bagi peneliti selanjutnya agar dapat menggunakan model lain dalam mengestimasi. Banyak alternatif model dan metode yang dapat digunakan peneliti selanjutnya untuk mendapatkan hasil yang lebih baik.

\section{DAFTAR PUSTAKA}

Boediono. (1992). Ekonomi moneter. BPFE: Yogyakarta.

Damodar, Gujarati dan Dawn, Porter. (2012). Dasar-dasar ekonometrika Buku 2. Edisi 5.Raden Carlos Mangunsong (penj.). Salemba Empat: Jakarta.

Hastuti.D; M.Edhie,Purnawan;\& S.Sunargo. (2018). Pengaruh variabel-variabel di sektor riil dan perbankan terhadap Shock Credit Default Swap (CDS) di Indonesia, e-Journal Perdagangan Industri dan Moneter, 6(2), 62-80

Mankiw, N. Gregory. (2000). Teori makro ekonomi. Erlangga: Jakarta.

Mustika,C; E Umiyati; \& E Achmad. (2015). Analisis pengaruh ekspor neto terhadap nilai tukar rupiah terhadap dolar Amerika Serikat dan pertumbuhan ekonomi di Indonesia, Jurnal Paradigma Ekonomika, 10 (2)

Purnomo, RSD. (2013). Buku pintar investasi dan gadai emas. Gramedia Pustaka Utama: Jakarta.

Samsul, M. (2006). Pasar modal \& manajemen portofolio. Erlangga: Jakarta.

Sindhu. (2013). A study of select factors on the price of Gold. Journal of Business and Management. 8 (4) ; 84-93

Sugiarto, dkk. (2002). Ekonomi mikro:sebuah kajian komprehensif. Gramedia Pustaka Utama: Jakarta.

Suharto, TF. (2013). Harga emas naik atau turun kita tetap untung. Elex Media Komputindo: Jakarta.

Tanuwidjaja, William. (2009). Cerdas investasi emas. Media Pressindo: Yogyakarta.

Tradelilin, Eduardus. (2010). Portofolio dan investasi teoridan aplikasi. Kanisius: Yogyakarta.

Tyson, E. (2011). Investing for dummies 8th Ed. John Wiley \& Son: Haboken.

Yudiarti,T; E Emilia; \& C Mustika. (2018).Pengaruh utang luar negeri, tingkat suku bunga dan neraca transaksi berjalan terhadap nilai tukar Rupiah terhadap Dolar Amerika Serikat, e-Jurnal Perdagangan Industri dan Moneter, 6 (1), 14-22 